\title{
Cold exposure and mammary glucose metabolism in the lactating goat
}

\author{
By A. FAULKNER, E. M. THOMSON,* J. M. BASSETT \\ AND G. E. THOMSON† \\ Hannah Research Institute, Ayr KA6 5 HL, Scotland and Nuffield Institute \\ for Medical Research, Oxford $O_{3} 9 D S$
}

(Received 29 May 1979 - Accepted I August 1979)

1. [U-14 C]glucose was infused intravenously into conscious lactating goats exposed to thermoneutral or cold environments for a total of $24 \mathrm{~h}$. The irreversible loss of glucose from the whole body and uptake of glucose by the mammary gland was measured and glucose utilization in the udder was studied by measuring the incorporation of radioactivity into carbon dioxide in mammary venous blood, into milk lactose and milk triglyceride-glycerol.

2. Exposure to cold increased the circulating level of glucose and slightly, though not significantly, increased the non-mammary irreversible loss of glucose.

3. The extraction of glucose from the circulation by the udder fell, the secretion of lactose by the udder also fell and this correlated closely with the reduced secretion of milk in the cold.

4. Simultaneous measurements of the concentrations of insulin, growth hormone and corticosteroids in the arterial plasma were made.

5. The plasma concentration of corticosteroids increased significantly in the cold.

6. It is concluded that reduced glucose uptake and lactose synthesis by the udder are important factors which reduce milk secretion during cold exposure.

When lactating cows (Cobble \& Herman, 195I) and goats (Clarke et al. I976) are exposed to a cold environment, there is a reduction in the volume of milk that they secrete. In the goat, this cannot be a consequence of a reduced udder blood flow only (Thompson \& Thomson, 1977), and an additional explanation must be sought. Milk consists of $900 \mathrm{ml} \mathrm{water/l}$ and the flow of water from blood to milk is probably by osmosis. Since lactose is the main osmolar component of milk, milk secretion rate depends on lactose secretion (Linzell \& Peaker, 197I). Normally, blood glucose is the only precursor of milk lactose (Hardwick et al. 1963) and, therefore, glucose uptake by the udder is important for milk secretion. Cold exposure is known to alter glucose metabolism in non-lactating animals, and blood glucose concentration, total turnover and oxidation of glucose are all increased (Depocas \& Masironi 1960); the output of glucose from the liver increases (Thompson et al. 1978) as does glucose uptake by the shivering muscle (Bell et al. 1975). In the present experiment, the effect of cold exposure on glucose uptake and utilization by the lactating mammary gland has been studied, and simultaneous measurements made of circulating levels of some hormones that may be responsible for changes in glucose metabolism.

\section{MATERIALS AND METHODS}

Animals. Five female British Saanen goats aged from 4 to 10 years, in their third to ninth lactations, and weighing 39-60 kg, were used. They were housed in an insulated byre and given hay ad lib. and $1200 \mathrm{~g}$ concentrates/d given in two equal meals at the times of milking ( 08.00 and 16.00 hours). Before lactation started, each animal had its right common carotid

* Present address: Max-Planck-Institut für Physiologische und Klinische Forschung, W. G. Kerckhoff Institut, Parkstrasse I, D 6350 Bad Nauheim, Germany.

$\uparrow$ Present address: Institute of Animal Physiology, Babraham, Cambridge CB2 4AT. 
artery exteriorized into a skin-covered loop, and blood vessels crossing between the two halves of the udder were ligated (Linzell, 1960a). Experiments were carried out between weeks 4 and 35 in lactation, when the animals were accustomed to experimental procedures and surroundings.

Experimental procedure. On the day before each experiment, a catheter was placed in a jugular vein and in the exteriorized carotid artery, and two catheters were placed in the left subcutaneous abdominal vein (Thompson \& Thomson, 1977) of the animal. The animal was then exposed to a thermoneutral $\left(20.0 \pm 1.0^{\circ}\right)$ or a moderately cold $\left(-0.5 \pm 0.5^{\circ}\right.$ and a wind speed of $2.6 \mathrm{~m} / \mathrm{s}$ ) environment at 16.30 hours on the day of the experiment. This moderately cold environment has previously been shown to increase the oxygen consumption of lactating goats by approximately $50 \%$ (Thompson \& Thomson, 1977). The sequence of environmental treatments was allocated randomly to each animal and at least $5 \mathrm{~d}$ elapsed between experiments on the same animal.

On the day of each experiment, the milk obtained at 08.00 hours was discarded. Blood samples were taken from the carotid artery, for estimation of insulin, growth hormone and corticosteroids, just before the 08.00 hours feeding and milking, and thereafter at $30 \mathrm{~min}$ intervals until 14.30 hours. At approximately 10.00 hours, a priming dose $(3.0 \mu \mathrm{Ci})$ of [U-14C]glucose (Radiochemical Centre, Amersham, Bucks) sterile saline (9 g sodium chloride $/ 1 ; 0.6 \mu \mathrm{Ci} / \mathrm{ml}, \mathrm{I} \mathrm{mg} / \mathrm{ml}$ ) was injected into the jugular vein, followed by an infusion $(0.3 \mu \mathrm{Ci} / \mathrm{min})$ which continued for $4 \mathrm{~h}$. This procedure produced a constant level of radioactivity in plasma glucose through sut the final $\mathrm{I} h$ of infusion. During the final $\mathrm{I} h$ of infusion, two sets of blood samples were taken from the carotid artery and subcutaneous abdominal vein for measurements of udder blood flow, plasma glucose specific activity and incorporation of radioactivity into venous blood carbon dioxide. Milk collected at 16.00 hours on the day of the experiment, and at 08.00 hours on the day after the experiment, was analysed for its specific activity of $\left[{ }^{14} \mathrm{C}\right]$ lactose and incorporation of radioactivity into triglyceride-glycerol. In preliminary experiments, no significant radioactivity was found in milk collected at $\mathbf{I} 6.00$ hours on the day after the experiment.

Measurements. Blood flow through the left half of the udder was measured as described previously (Thompson \& Thomson, 1977). Briefly, the left external pudic vein was manually occluded, which ensures that all and only mammary blood leaves the gland via the subcutaneous abdominal vein (Linzell, 1960 a), and then indocyanine green dye (Cardio-Green; Hynson, Westcott and Dunning, Baltimore, USA) was infused upstream into the subcutaneous abdominal vein and its dilution measured in blood samples taken downstream, and its recirculation measured in samples simultaneously taken from the carotid artery. Packed cell volume was measured after spinning blood samples for $8 \mathrm{~min}$ at $12000 \mathrm{~g}$ and used to calculate plasma flow from blood-flow values.

Plasma glucose concentrations were measured enzymically (Slein, 1963). In preliminary experiments, glucose was not detected in erythrocytes. Radioactive glucose was isolated from plasma as the penta-acetate derivative (Jones, 1965) and radioactivity in whole blood bicarbonate was measured as sodium hydroxide-trapped ${ }^{14} \mathrm{CO}_{2}$ after acidification of $2 \mathrm{ml}$ blood with $2 \mathrm{ml}$ I M-perchloric acid in an airtight vessel (Lin \& Fritz, 1972). Lactose was isolated from milk (Wood et al. 1965) and a sample assayed for radioactivity using Unisolve (Koch-Light Laboratories, Colnbrook, Bucks.); a further sample was hydrolysed and the concentration of glucose in the hydrolysate assayed enzymically (Slein, I963). Milk fat was isolated by centrifugation (Wood et al. 1965), washed with saline, and radioactivity in glyceride-glycerol determined (Vernon, 1977).

Radioactivity was measured in a conventional liquid-scintillation counter.

The concentrations of growth hormone (Wallace \& Bassett, 1970), insulin (Bassett \& Thorburn, 197I) and cortisol (Abraham et al. I972) were measured by radioimmunoassay. 
Calculations. Uptake $(U)$ of glucose $(\mu \mathrm{mol} / \mathrm{min})$ by the mammary gland was calculated from the equation:

$$
U=Q_{P} \times\left((\text { glucose })_{A}-(\text { glucose })_{V}\right),
$$

where $Q_{P}$ is the mammary plasma flow $(\mathrm{ml} / \mathrm{min})$, (glucose) ${ }_{A}$ is the arterial plasma glucose concentration $(\mu \mathrm{mol} / \mathrm{ml})$ and (glucose $)_{V}$ is the mammary venous plasma glucose concentration $(\mu \mathrm{mol} / \mathrm{ml})$.

Release $(R)$ of ${ }^{14} \mathrm{CO}_{2}$ into mammary venous blood ( $\mu$ mol glucose incorporated into $\mathrm{CO}_{2} / \mathrm{min}$ ) was calculated from the equation:

$$
\left.R=Q_{B} \times\left(\left({ }^{14} \mathrm{CO}_{2}\right)_{V}-\left({ }^{14} \mathrm{CO}_{2}\right)_{A} /\left({ }^{14} \mathrm{C}\right] \mathrm{glucose}\right)_{A}\right),
$$

where $Q_{B}$ is the mammary blood flow $(\mathrm{ml} / \mathrm{min}),\left({ }^{14} \mathrm{CO}_{2}\right)_{V}$ is the mammary venous blood ${ }^{14} \mathrm{CO}_{2}(\mu \mathrm{Ci} / \mathrm{ml}$ blood $),\left({ }^{14} \mathrm{CO}_{2}\right)_{A}$ is the arterial blood ${ }^{14} \mathrm{CO}_{2}(\mu \mathrm{Ci} / \mathrm{ml} \mathrm{blood}),\left(\left[{ }^{14} \mathrm{C}\right] \text { glucose }\right)_{A}$ is the mean specific activity of glucose in arterial plasma at equilibrium $(\mu \mathrm{Ci} / \mathrm{mol})$.

Release $(R)$ of $\left[{ }^{14} \mathrm{C}\right]$ lactose or $\left[{ }^{14} \mathrm{C}\right]$ glyceride-glycerol into milk ( $\mu \mathrm{mol}$ glucose incorporated/ $\mathrm{min})$ was calculated from the equation:

$$
R=\left({ }^{14} \mathrm{C}\right)-\text { milk } / t \times\left(\left[{ }^{14} \mathrm{C}\right] \text { glucose }\right)_{A},
$$

where $\left({ }^{14} \mathrm{C}\right)$-milk is the total yield of ${ }^{14} \mathrm{C}$ activity in milk lactose or glycerol collected after $\left[\mathrm{U}^{14} \mathrm{C}\right]$ glucose infusion $(\mu \mathrm{Ci}), t$ is the total time of $\left[{ }^{14} \mathrm{C}\right]$ glucose infusion (min).

The irreversible loss $(L)$ of glucose in the whole body $(\mu \mathrm{mol} / \mathrm{min})$ was calculated from the equation:

$$
L=I /\left(\left[{ }^{14} \mathrm{C}\right] \mathrm{glucose}\right)_{A},
$$

where $I$ is the rate of infusion of $\left[\mathrm{U}^{14} \mathrm{C}\right] \mathrm{glucose}(\mu \mathrm{Ci} / \mathrm{min})$.

Statistics. Results obtained in the cold environment were compared with those obtained in the neutral environment using the Student's paired $t$ test. The absolute concentrations of many hormones are not normally distributed but their $\log _{10}$ often are (Bassett \& Thorburn, I 97I). Therefore concentrations of hormones were converted to $\log _{10}$ for all statistical procedures. For clarity in the figures, results are illustrated as the anti $\log _{10}$ of the mean.

\section{RESULTS}

Mammary blood flow, circulating glucose concentrations and mammary glucose utilization

Cold exposure reduced, though not significantly, the flow of blood plasma through the mammary gland (Table I). Flow was reduced by $45 \%$ or more in three animals but was unchanged in the remaining two. Arterial plasma glucose concentration increased $(P<0.05)$ in the cold. The net effect of these two changes was to reduce the supply of glucose, by the arterial circulation, to the udder from $746 \mu \mathrm{mol} / \mathrm{min}$ in the thermoneutral environment to $472 \mu \mathrm{mol} / \mathrm{min}$ in the cold. In addition, the percentage extraction of glucose from the circulation by the udder decreased from 28 to $14(P<0.05)$ and the difference between the concentration of glucose in arterial and mammary venous blood dropped by $4 \mathrm{I} \%$ $(P<0.05)$ thus reducing the net mammary glucose uptake by $70 \%(P<0.05)$. Values for the specific activity of $\left[{ }^{14} \mathrm{C}\right]$ glucose in mammary venous blood were similar to those in arterial blood, therefore the udder did not release unlabelled glucose into the circulation and the values for net glucose uptake were measurements of real uptake.

Lactose output in milk fell during cold exposure to $30 \%$ of its value in a thermoneutral environment $(P<0.01)$. Milk secretion rate was highly correlated with lactose secretion rate in both environments (Fig. I) and milk secretion rate also fell during cold exposure $(P<0.01)$, whereas lactose concentration in milk did not change. 
Table $\mathrm{I}$. The effect of $24 \mathrm{~h}$ cold exposure on glucose concentration in arterial (A) and mammary venous (V) plasma, plasma flow and glucose metabolism in half the mammary gland of five lactating goats

(Mean values with their standard errors)

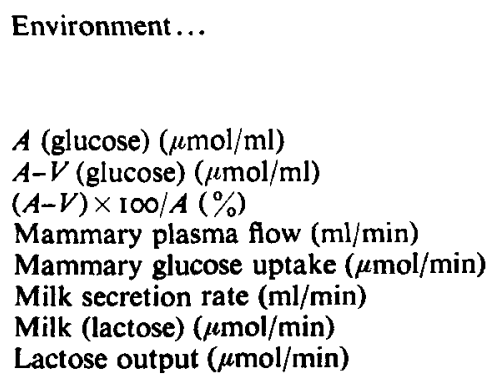

Environment...

$A$ (glucose) $(\mu \mathrm{mol} / \mathrm{ml})$

$A-V$ (glucose) $(\mu \mathrm{mol} / \mathrm{ml})$

$(A-V) \times 100 / A(\%)$

Mammary plasma flow $(\mathrm{ml} / \mathrm{min})$

Mammary glucose uptake $(\mu \mathrm{mol} / \mathrm{min})$

Milk secretion $\mathrm{rate}(\mathrm{ml} / \mathrm{min})$

Milk (lactose) $(\mu \mathrm{mol} / \mathrm{min})$

Lactose output $(\mu \mathrm{mol} / \mathrm{min})$

\begin{tabular}{ccccc}
\multicolumn{2}{c}{ Thermoneutral } & \multicolumn{2}{c}{ Cold } \\
Mean & SE & & Mean & SE \\
3.27 & 0.05 & & 3.84 & $0.17^{*}$ \\
0.92 & 0.18 & 0.54 & $0.09^{*}$ \\
28.4 & 5.8 & 14.0 & $2.8^{*}$ \\
228 & 34 & 123 & 30 \\
216 & 66 & 66 & $25^{*}$ \\
0.572 & 0.101 & 0.176 & $0.038^{* *}$ \\
148 & 3 & 148 & 5 \\
85 & 15 & 26 & $5^{* *}$
\end{tabular}

[U.-14 C]glucose $(\mu \mathrm{mol} / \mathrm{min})$ incorporated into:

Lactose

Glyceride-glycerol

Carbon dioxide

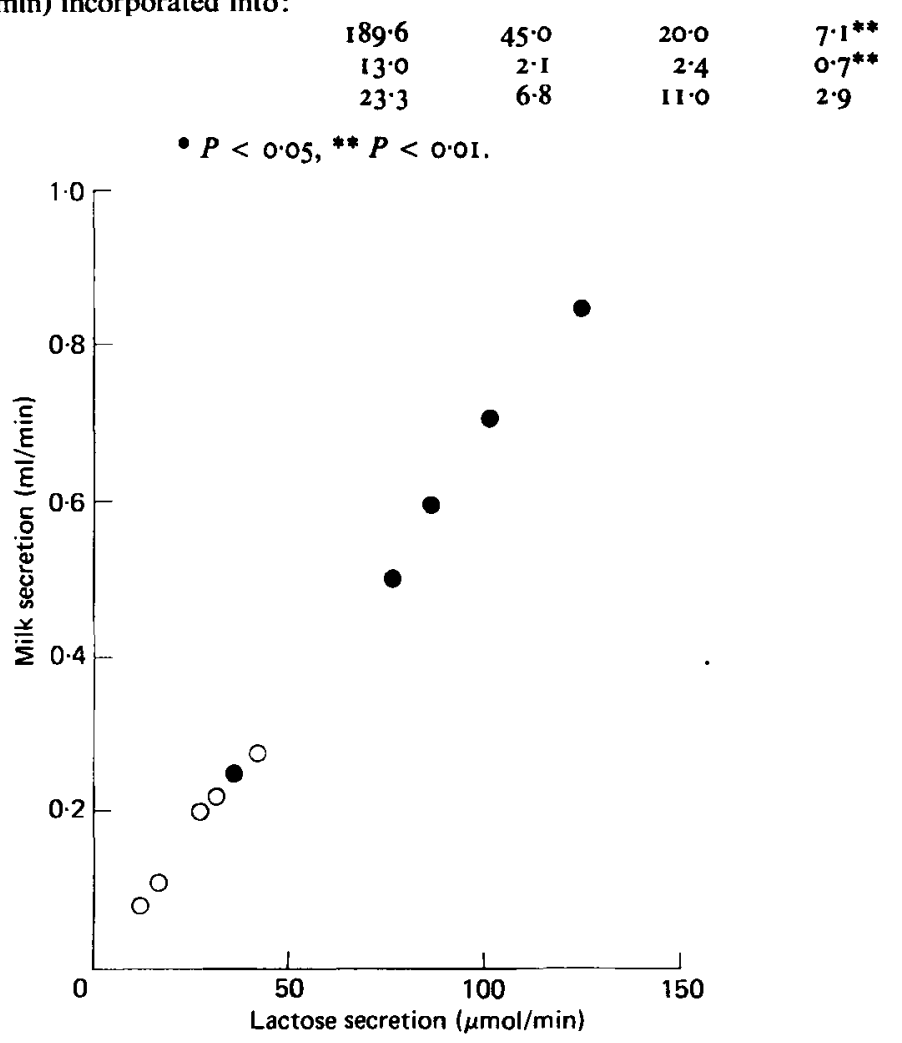

Fig. I. Relationship between lactose secretion $(\mu \mathrm{mol} / \mathrm{min})$ and milk secretion $(\mathrm{ml} / \mathrm{min})$ in five goats exposed to thermoneutral $(\bullet)$ and cold $(O)$ environments.

The amount of labelled glucose taken up by the udder which appeared as lactose $(P<$ $0.05)$ or glycerol $(P<0.01)$ in the milk decreased in the cold by $90 \%$ and $80 \%$ respectively. The amount of labelled glucose which was oxidized to $\mathrm{CO}_{2}$ also tended to decrease, although this change was not statistically significant. The mass of lactose secreted in the milk accounted for approximately $80 \%$ of the mass of glucose taken up by the mammary gland in both thermoneutral and cold environments. However, the specific activity ratio, milk 
Table 2. The effect of $24 h$ cold exposure on glucose metabolism in the whole mammary gland and body of five lactating goats

(Mean values with their standard errors)

\begin{tabular}{|c|c|c|c|c|}
\hline \multirow[t]{2}{*}{ Environment... } & \multicolumn{2}{|c|}{ Thermoneutral } & \multicolumn{2}{|c|}{ Cold } \\
\hline & Mean & $\mathbf{S E}$ & Mean & $\mathbf{S E}$ \\
\hline $\begin{array}{l}\text { Calculated glucose uptake by } \\
\text { gland ( } \mu \mathrm{mol} / \mathrm{min}) \\
\text { Irreversible loss of glucose }\end{array}$ & 421 & 125 & 127 & $45^{*}$ \\
\hline $\begin{array}{l}\text { by whole body ( } \mu \mathrm{mol} / \mathrm{min}) \\
\text { Whole mammary loss of glucose }\end{array}$ & 1063 & 97 & 844 & 22 \\
\hline & 38 & 9 & 15 & $6^{* *}$ \\
\hline loss of glucose $(\mu \mathrm{mol} / \mathrm{min})$ & 642 & 95 & 717 & 58 \\
\hline
\end{tabular}

lactose:plasma glucose fell by more than $50 \%$ in the cold environment from $I \cdot 7 \mathrm{I}$ to 0.78 (difference $0.93 \pm 0.29, P<0.01$ ).

\section{Glucose utilization in the rest of the body}

Cold exposure caused a small, though not significant, decrease in the rate at which glucose was irreversibly lost from the whole body. To distinguish mammary and non-mammary use of glucose, values for glucose uptake by the whole mammary gland have been calculated from measurements of uptake by half the gland and milk yield of both halves of the gland, assuming proportionality between glucose uptake and milk yield. The results (Table 2) show that the effect of cold exposure on the whole body is largely due to its effect on the whole mammary gland. Utilization of glucose by non-mammary tissue is slightly, though not significantly, increased during cold exposure.

The control values, obtained in the present study, for irreversible loss of glucose from the whole body, mammary glucose uptake and mammary glucose utilization are similar to those previously reported for goats with comparable milk yields (Annison \& Linzell, 1964).

\section{Arterial plasma growth hormone concentration}

In the thermoneutral environment, plasma growth hormone concentration fell 60 min after feeding and milking, to a value lower than the average for the rest of the day (difference in $\log _{10}$ concentration (mean \pm SE) of $0.212 \pm 0.026 \mathrm{ng} / \mathrm{ml}, P<0.01$ ) (Fig. 2). There was no similar change after feeding in the cold environment. The average values, throughout the day, in the two environments were not significantly different.

\section{Arterial plasma insulin concentration}

In both environments, plasma insulin concentration increased $90 \mathrm{~min}$ after feeding and milking, to a value higher than the average for the rest of the day $(0.19 \pm 0.05, P<0.05)$ (Fig. 2). Over the period 10.30 hours to 14.00 hours, the average insulin concentration was higher in the cold environment than in the thermoneutral environment $(0.136 \pm 0.031$, $P<0.02$ ).

The increased arterial plasma insulin concentration and decreased growth hormone concentration which occurred after feeding and milking in a thermoneutral environment, in the present study, have been previously reported to occur after feeding of male sheep (Bassett, 1974). 

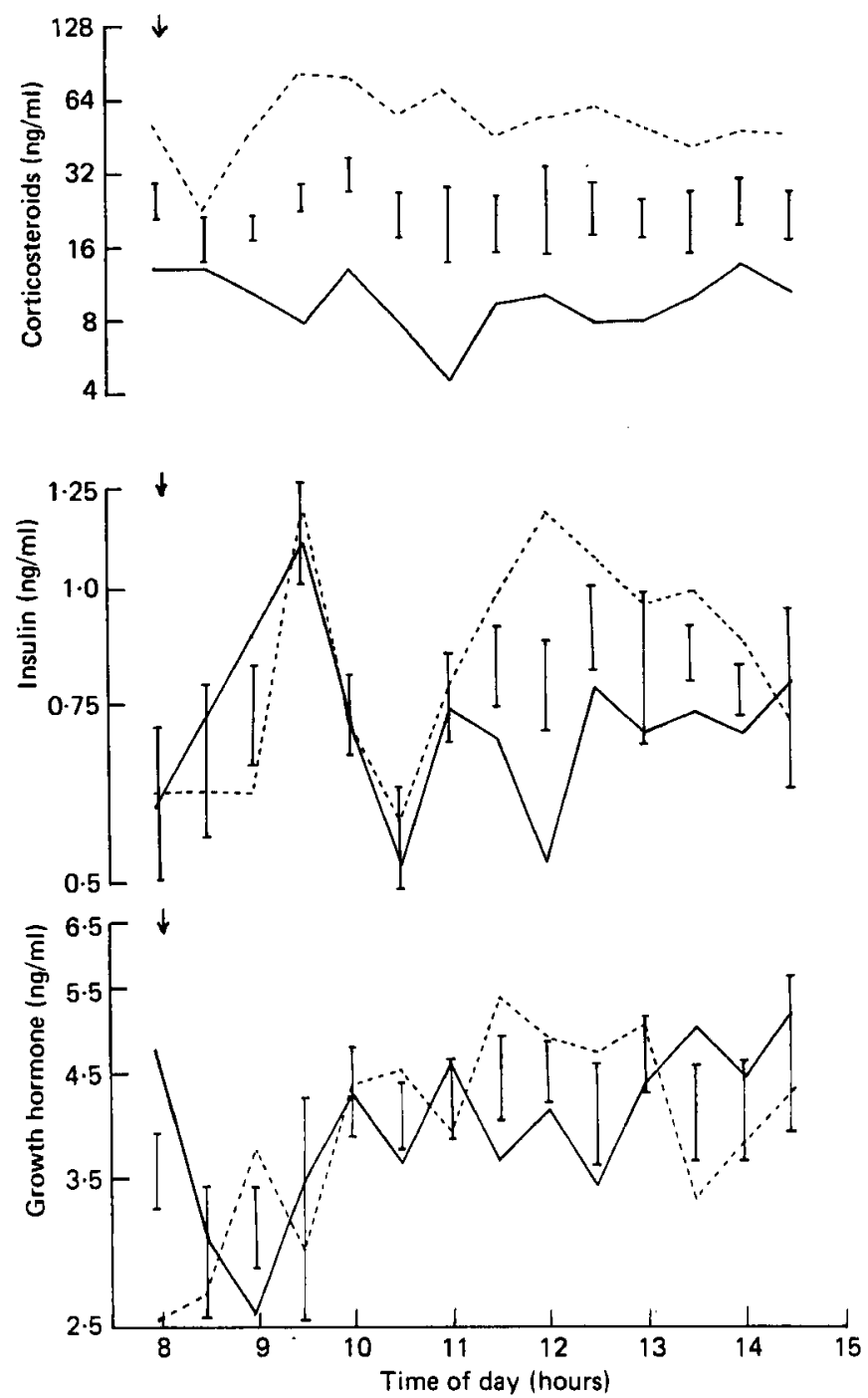

Fig. 2. Arterial plasma corticosteroid, insulin and growth hormone concentrations $(\mathrm{ng} / \mathrm{ml})$ in thermoneutral (-) and cold (-) environments. Values are means for five animals, with their standard errors represented by vertical bars $\downarrow$, fed and milked.

\section{Arterial plasma cortisol concentration}

In the thermoneutral environment, plasma corticosteroid concentration did not change after feeding and milking, but remained relatively constant throughout the day (Fig. 2). In the cold environment, the average level throughout the day was higher than thermoneutral values $(0.78 \pm 0.12, P<0.01)$ and, in the cold, there was a decrease $30 \mathrm{~min}$ after feeding to a value lower than the average for the rest of the day $(0.40 \pm 0.09, P<0.02)$. 
DISCUSSION

Cold exposure increases the irreversible loss of glucose from the non-lactating ruminant (McKay et al. 1974). The opposite effect was found in lactating goats in the present experiments, but was shown to be due to a reduced uptake of glucose by the mammary gland; the rest of the body responded in the same way as the non-lactating animal. Changes in mammary glucose metabolism are likely to have a major impact on the over-all body glucose metabolism, since it has been shown that lactose synthesis can account for some $80 \%$ of non-oxidized glucose in the sheep (Bergman \& Hogue, 1967) and goat (Annison \& Linzell, 1964).

The decrease in mammary glucose uptake during cold exposure was due to a reduced extraction of glucose from the circulation. Previously published measurements of mammary glucose extraction, in a thermoneutral environment and over a naturally occurring range of circulating glucose concentrations, have found it to be constant (Linzell, 1960b). The reduced extraction in the cold was not associated with any consistent change in the circulating levels of growth hormone or insulin, but corticosteroid levels were increased. Increased blood corticosteroid levels during cold exposure have been previously reported (Panaretto \& Vickery, 1970) and the present experiments have shown that these high levels are briefly reduced after feeding and milking in the cold. It is not known whether corticosteroids, in physiological doses, reduce glucose uptake by mammary tissue. A large dose of dexamethasone reduces glucose uptake by the udder of the lactating cow (Hartmann \& Kronfeld, I973); however, infusion of cortisol into lactating goats for $4 \mathrm{~h}$, which produced plasma levels similar to those produced by cold exposure in the present study, slightly stimulated milk secretion (Paterson \& Linzell, I97I) which is not consistent with a reduced glucose uptake. However, infusion over longer time intervals may give different results.

The fate of glucose in the mammary gland during cold exposure has not been clarified by the present experiments. The mass of lactose secreted in milk accounted for a constant $80 \%$ of glucose uptake in both environments, but there was a decrease in the specific activity of the lactose secreted which cannot be explained satisfactorily at the moment. Dilution of radioactive glucose by unlabelled glucose in the udder could occur in a number of ways. Although there is no evidence for gluconeogenesis as such in the ruminant udder (Scott et al. 1976), the bovine udder possesses the enzymes necessary for the synthesis of the galactose moiety of lactose from non-carbohydrate precursors in blood (Baird, 1969). The tissue also contains a small amount of glycogen (Knodt \& Petersen, 1945) and, as cold exposure is known to cause glycogenolysis in the liver (Depocas \& Masironi, 1960) similar breakdown of glycogen may occur in the mammary gland to partially compensate for its reduced glucose uptake. There were also reductions in the apparent transfer of ${ }^{14} \mathrm{C}$ label to blood $\mathrm{CO}_{2}$ and milk triglyceride-glycerol during cold exposure.

In the thermoneutral environment, the production of radioactive $\mathrm{CO}_{2}$ and of milk lactose and triglyceride-glycerol accounted for all the glucose taken up by the udder. In the moderately cold environment, however, only $50 \%$ of the glucose taken up by the udder can be accounted for in this way. It has been shown previously that glucose carbon can be used by the mammary gland for amino acid synthesis for milk protein production (Linzell \& Mepham, 1968) or released as lactate (Robinson \& Williamson, I977). If release of radioactive lactate (which could be resynthesized to glucose in the liver) were occurring in the goat udder, this would reduce still further the irreversible mammary loss of glucose relative to the whole body loss in the cold-exposed animal.

The very close correlation between mass of lactose secreted and volume of milk secreted, in the neutral and cold environments, suggests that reduced mammary glucose uptake and reduced lactose secretion are major factors responsible for the reduced secretion of milk during cold exposure. It is possible that changes in the circulating levels of hormones seen 
during cold exposure may be responsible for this regulation of glucose metabolism in the mammary gland.

The authors wish to thank Dr H. Shelley for supervising the cortisol assays, Mrs H. Hackling and Miss $\mathrm{H}$. Kennedy for expert technical assistance and $\mathrm{Mr} \mathrm{T}$. Hutchison for caring for the animals.

\section{REFERENCES}

Abraham, G. E., Buster, J. E. \& Teller, R. C. (1972). Analyt. Lett. 5, 757.

Annison, E. F. \& Linzell, J. L. (1964). J. Physiol., Lond. 175, 372.

Baird, G. D. (1969). Biochim, biophys. Acta 177, 343.

Bassett, J. M. (1974). Aust. J. biol. Sci. 27, 167.

Bassett, J. M. \& Thorburn, G. D. (1971). J. Endocr. 50, 59

Bell, A. W., Gardner, J. W., Manson, W. \& Thompson, G. E. (1975). Br. J. Nutr. 33, 207.

Bergman, E. N. \& Hogue, D. E. (1967). Am. J. Physiol, 213, 1378.

Clarke, P. L., Thomson, E. M. \& Thompson, G. E. (1976). J. Physiol., Lond. 263. 176 P.

Cobble, J. W. \& Herman, H. A. (1951). Res. Bull. Mo. Agric. Exp. Sin. no. 485.

Depocas, F. \& Masironi, R. (1960). Am. J. Physiol. 199, I051.

Hardwick, D. C., Linzell, J. L. \& Mepham, T. B. (1963). Biochem. J. 88, 213.

Hartmann, P. E. \& Kronfeld, D. S. (1973). J. Diary Sci. 56, 896.

Jones, G. B. (1965). Analyt. Biochem. r2, 249.

Knodt, C. B. \& Petersen, W. E. (1945). J. Dairy Sci. 28, 415.

Lin, C. H. \& Fritz, I. B. (1972). Can. J. Biochem. 50, 963.

Linzell, J. L. (1960a). J. Physiol., Lond. 153, 48I.

Linzell, J. L. (1960b). J. Physiol., Lond. 153, 492.

Linzell, J. L. \& Mepham, T. B. (1968). Biochem. J. $107,18$.

Linzell, J. L. \& Peaker, M. (1971). Physiol. Rev. 51, 564.

McKay, D. G., Young, B. A. \& Milligan, L. P. (1974). In Energy Metabolism of Farm Animals, pp. 39-42. Hohenheim: Universität Hohenheim Dokumentationsstelle.

Panaretto, B. A. \& Vickery, M. R. (1970). J. Endocr. 47, 273.

Paterson, J. Y. F. \& Linzell, J. L. (1971). J. Endocr. 50, 593.

Robinson, A. M. \& Williamson, D. H. (1977). Biochem. J. 164, I 53.

Scott, R. A., Baumen, D. E. \& Clark, J. H. (1976). J. Dairy Sci. 59, 50.

Slein, M. W. (1963). In Methods of Enzymatic Analysis, pp. 11 7-123 (H. U. Bergmeyer, editor). New York: Academic Press.

Thompson, G. E., Manson, W., Clarke, P. L. \& Bell, A. W. (1978). Q. Jl exp. Physiol. 63, 189.

Thompson, G. E. \& Thomson, E. M. (1977). J. Physiol., Lond. 272, 187.

Vernon, R. G. (1977). Int. J. Biochem. 8, 517.

Wallace, A. L. C. \& Bassett, J. M. (1970). J. Endocr. 47, 2 I.

Wood, H. G., Peeters, G. J., Verbeke, R., Lauryssens, M. \& Jacobson, B. (1965). Biochem. J. 96, 607. 